\title{
Comparison of fatty acid profiles of edible meat, adipose tissues and muscles between cocks and capons
}

\author{
Marc TOR $^{\mathrm{a} *}$, Joan ESTANY ${ }^{\mathrm{a}}$, Amadeu FRANCESCH ${ }^{\mathrm{b}}$, Maria Dolors CUBILÓ $^{\mathrm{a}}$
}

a Departament de Producció Animal, UdL, Rovira Roure, 191, 25198 Lleida, Spain

b Unitat Genètica Avícola, Centre Mas Bové, IRTA, Apartat 415, 43280 Reus, Spain

(Received 4 November 2004; accepted 23 May 2005)

\begin{abstract}
The effect of caponisation on fat composition by parts (wing, breast, thigh, and drumstick) and tissues (skin, subcutaneous adipose tissue, intermuscular adipose tissue and muscle) was examined in the present study and fatty acid profiles of abdominal fat and edible meat by parts and tissue components were determined. The sample was made up of twenty-eight castrated and twenty male Penedesenca Negra chicks reared under free-range conditions and slaughtered at 28 wk of age; the birds were castrated at four or eight weeks. Caponisation significantly increased $(P<0.01)$ the chemical fat content in all parts ( $16.31 \%$ to $37.98 \%$ in breast; $21.98 \%$ to $34.13 \%$ in wing; $21.09 \%$ to $49.57 \%$ in thigh; $14.33 \%$ to $24.82 \%$ in drumstick) and led to minor modifications in fat characteristics, particularly in the thigh and the drumstick, where the unsaturated vs. saturated fatty acid ratio increased from 1.31 to $1.76(P<0.01)$ and from 1.48 to $2.07(P<0.01)$, respectively. Delaying the age of castration from 4 to 8 weeks increased this ratio by 0.35 in the edible meat. Even though the profile of the abdominal fat is less saturated in capons, all changes occurring on fat quality after caponisation indicate that increased fatness after castration does not imply worse fat nutritional properties.
\end{abstract}

chicken / capon / edible meat / fatty acids

Résumé - Comparaison de la composition lipidique de la viande, des tissus adipeux et des muscles de coqs et de chapons. Les effets de la castration sur la composition de la graisse de différents morceaux (ailes, filets, cuisses, pilons) et de tissus (peau, graisse sous cutanée, tissus adipeux intermusculaires et muscles) ont été mesurés dans la présente étude. Les profils en acides gras (AG) de la graisse abdominale et des morceaux ont été déterminés. Les prélèvements ont été faits sur 28 chapons et 20 coqs Penedesenca Noirs élevés en plein air et sacrifiés à l'âge de 28 semaines, le chaponnage étant réalisé à l'âge de 4 ou de 8 semaines. Le chaponnage fait augmenter significativement $(P<0,01)$ la concentration en graisse de tous les morceaux (de 16,31 à 37,98\% dans les filets; de 21,98 à $34,13 \%$ dans les ailes; de 21,09 à $49,57 \%$ dans les cuisses et de 14,33 à 24,82\% dans les pilons, en moyenne) et induit quelques modifications mineures des caractéristiques des graisses, particulièrement dans les cuisses et les pilons. Le chaponnage fait augmenter le rapport AG insaturés/AG saturés de 1,31 à $1,76(P<0,01)$ et de 1,48 à $2,07(P<0,01)$ dans les cuisses et les pilons, respectivement. En retardant l'âge de la castration de 4 à 8 semaines, ce rapport augmente

\footnotetext{
* Corresponding author: mtor@prodan.udl.es
} 
de 0,35 en moyenne dans la viande consommée. Bien que le profil en AG de la graisse abdominale soit moins saturé chez les chapons, l'ensemble des changements se produisant sur la qualité des graisses après chaponnage suggère que l'engraissement supérieur des chapons n'implique pas une réduction de la qualité nutritionnelle des graisses.

poulet / chapon / viande / acides gras

\section{INTRODUCTION}

Caponisation in poultry has been a common practice for centuries to improve and maintain meat quality throughout the year [24]. Nowadays, although its consumption is strongly seasonal in the Mediterranean area, capons are considered a source of prestigious and high-priced meat. There are few works that have attempted to characterise caponisation effects; however, in a previous work we analysed the effects of caponisation on carcass distribution and tissue composition [23]. In line with other works $[4,26]$, our results showed that the main effects of caponisation are related to fat deposition: capons have more abdominal, subcutaneous and intramuscular fat than cocks. In particular, at the same age, the abdominal fat in capons is around sixfold heavier than in cocks. Moreover, the correlation between abdominal fat with subcutaneous and intramuscular fat was 0.86 and 0.40 respectively. The strong changes occurring in fat contents caused by caponisation may change the fat quality of edible meat as well. This is a matter of increasing importance, mainly for two reasons: (1) its impact on meat sensory properties and (2) its implications in human health [2]. It is commonplace that high intramuscular fat contents improve meat sensory properties, although this may not be necessarily the case in poultry, where meat from leaner lines could be preferred by consumers [15]. With regards to fat composition, low changes in fatty acid profiles are enough to modify sensory characteristics of the meat [17]. It is, however, generally accepted that a high plasma level of LDL-cholesterol in human blood is correlated with coronary heart disease [12], and that saturated fatty acids increase the plasma LDL-cholesterol level whereas unsaturated fatty acids decrease it [13].

In this sense, the objective of this paper was to investigate the differences between capons and cocks in the fatty acid profiles of abdominal fat and of edible meat. Since the consequences of caponisation differed among parts, in order to get an in-deep representation of different responses to caponisation, fatty acid profiles were calculated part by part for each constituent tissue.

\section{MATERIALS AND METHODS}

The experimental procedures by means of which this study was conducted were approved by the Ethics Committee for Animal Experimentation of the University of Lleida.

\subsection{Animals, rearing procedures and carcass dissection}

Most of the experimental procedures concerning animals, rearing practice and carcass dissection are described in a previous paper [23]. Briefly, a random sample of 20 capons (late caponisation; CA-8) and 20 cocks (CK) was taken from two batches of Black Penedesenca-based birds [9]. Some of the birds in the first batch were castrated at 4 weeks of age (early castration; CA-4), and 8 of them were taken for this trial as well. Caponisation was done following the surgical method described in Cubiló et al. [6]. All birds were fed with the same diet (Tab. I) and reared according to the official requirements of quality poultry production in Catalonia, Spain [7]. Feed nutrient contents were determined as follows: crude 
Table I. Estimated nutrient content of the diet fed during the trial.

\begin{tabular}{lc}
\hline Nutrient contents & \\
\hline ME (kcal per kg) & 3200 \\
Crude protein (\%) & 20.7 \\
Methionine (\%) & 0.35 \\
Ash (\%) & 6.26 \\
Crude lipid (\%) & 3.3 \\
Fatty acid composition (\%) & \\
C16:0 & 21.51 \\
C16:1 n-7 & 0.78 \\
C18:0 & 8.98 \\
C18:1 n-9 & 27.66 \\
C18:2 n-6 & 39.04 \\
C18:3 n-3 & 2.04 \\
SFA & 30.49 \\
MUFA & 28.44 \\
PUFA & 41.08 \\
MUFA+PUFA/SFA & 2.28 \\
\hline
\end{tabular}

SFA, MUFA, PUFA: Saturated, Mono-Unsaturated and Poly-Unsaturated Fatty Acids, respectively. The diet was formulated according to the official requirements of quality poultry production in Catalonia, Spain and contains at least $70 \%$ of cereals.

protein and ash analyses were conducted according to the Association of Official Analytical Chemists (AOAC, 1990). Crude lipids were determined by ether extraction in a Soxhlet apparatus. Compositional fat analysis was performed by gas chromatography with a capillary column and a flame ionisation detector. The absence of testicular regeneration in capons was determined on live by visual assessment and later confirmed after slaughtering. At 28 weeks of age, the animals were stunned, slaughtered and bled in a commercial slaughterhouse. After evisceration, the carcasses were chilled in $\mathrm{a} 4^{\circ} \mathrm{C}$ cool room for $24 \mathrm{~h}$ and quartered according to the WPSA recommendations [25]. The left-side wing (WG), breast (BR), thigh (TH) and drumstick (DK) were dissected into the following tissues: skin (SK), subcutaneous adipose tissue (SB), intermuscular adipose tissue (IM), muscle
(M), bone (B) and tendons; edible meat was defined as the sum of all the edible tissues in the part $(\mathrm{SK}+\mathrm{SB}+\mathrm{IM}+\mathrm{M})$. To obtain a representative sample of the edible meat of each dissected part, an aliquot was taken from the pool originated after mixing SK, SB, IM, and M. Moreover, SK, SB, IM, and $M$ from all dissected parts of 12 CA- 8 and $12 \mathrm{CK}$ birds were analysed separately to determine the fatty acid profile of each tissue component. In these animals, the edible meat fat characteristics of each part were calculated as a weighed mean of the values in each tissue.

\subsection{Determination of fatty acid profiles}

Previously to fatty acid determinations, the samples of edible meat and tissue components were minced and freeze-dried. After homogenisation, representative aliquots from freeze-dried samples were used to determine dry matter (DM) and crude fat content. DM was determined by drying a precise weight at 100 to $102{ }^{\circ} \mathrm{C}$ in an air oven for 24 hours. Crude fat content was determined by ether extraction in a Soxhlet device while percent crude fat was calculated on dry tissue basis. These chemical analyses were conducted according to the Association of Official Analytical Chemist regulations [3]. For fatty acid analysis, total lipids were extracted using a chloroform/methanol mixture [11]. Fatty acid methyl esters were obtained using a solution of boron trifluoride $20 \%$ in methanol [20]. Analysis of fatty acid methyl esters were performed by gas chromatography with a capillary column SP2330 (Supelco, Tres Cantos, Madrid) and a flame ionisation detector with helium as the carrier gas. The oven temperature program increased from 150 to $225^{\circ} \mathrm{C}$ at $7{ }^{\circ} \mathrm{C}$ per min. Injector and detector temperatures were both $250^{\circ} \mathrm{C}$. The quantification was carried out through area normalisation with an external standard mixture of fatty acid methyl esters (Sigma, Tres Cantos, Madrid). Fatty acid composition was calculated as a percentage of each individual fatty acid relative to total fatty acids; other 
details of the fat analysis can be seen in Tor [22]. Several indexes were obtained from individual fatty acid percentages; in particular, proportions of polyunsaturated (PUFA), monounsaturated (MUFA), saturated (SFA) fatty acids and the unsaturated:saturated (US) ratio were calculated.

\subsection{Statistical analyses}

Data analysis was performed using the SAS general linear models (GLM) procedure [21]. The analysis for fatty acid profile of the abdominal fat was performed according to the following model:

$$
\mathrm{y}_{\mathrm{ijk}}=\mu+\mathrm{b}_{\mathrm{i}}+\mathrm{s}_{\mathrm{j}}+\mathrm{bX}_{\mathrm{ijk}}+\mathrm{e}_{\mathrm{ijk}}(1)
$$

where $y_{i j}$ is the fatty acid percentage being analysed in individual $\mathrm{k}$ of batch $\mathrm{i}$ and sexual group $j ; \mu$ is the overall mean; $b_{i}$ is the batch effect $\mathrm{i}(\mathrm{i}: 1,2) ; \mathrm{s}_{\mathrm{j}}$ is the sexual group (j: CA-8, CK) or age of caponisation (j: $4 \mathrm{wk}, 8 \mathrm{wk})$; b is the regression coefficient for $\mathrm{X}_{\mathrm{ijk}}$, and $\mathrm{e}_{\mathrm{ijk}}$ is the residual error term. The covariable $X_{i j k}$ was included in the model in order to adjust the differences between sex groups for abdominal fat content. Thus, $\mathrm{X}_{\mathrm{ijk}}$ was the abdominal fat weight of individual $\mathrm{k}$.

The analyses for fat content and fatty acid profiles of edible meat were performed according to the following model:

$$
\mathrm{y}_{\mathrm{ijk} k}=\mu+\mathrm{b}_{\mathrm{i}}+\mathrm{s}_{\mathrm{j}}+\mathrm{p}_{\mathrm{k}}+\mathrm{sp}_{\mathrm{jk}}+\mathrm{bX}_{\mathrm{ijkl}}+\mathrm{e}_{\mathrm{ijkl}}
$$

where $y_{i j k l}$ is the fatty acid percentage being analysed in part $\mathrm{k}$ from an individual $\mathrm{l}$ of sexual group $\mathrm{j}$ and batch $\mathrm{i} ; \mu, \mathrm{b}_{\mathrm{i}}, \mathrm{s}_{\mathrm{j}}$, and $\mathrm{b}$ are defined as above; $p_{k}$ is the part effect $\mathrm{k}$ (k: WG, BR, TH, DK) or age of caponisation (j: $4 \mathrm{wk}, 8 \mathrm{wk}) ; \mathrm{sp}_{\mathrm{jk}}$, is the second order interaction between the sexual group and the part effects and $\mathrm{e}_{\mathrm{ijkl}}$ is the residual error term. In fatty acid profiles, the covariable $\mathrm{X}_{\mathrm{ijkl}}$ was included in the model in order to adjust the differences between sex groups for crude fat content of edible meat (EMF). Thus, $\mathrm{X}_{\mathrm{ijkl}}$ was EMF of individual 1 .
Fatty acid profiles in each tissue were analysed according to the following model:

$$
\begin{aligned}
\mathrm{y}_{\mathrm{jklm}} & =\mu+\mathrm{s}_{\mathrm{j}}+\mathrm{p}_{\mathrm{k}}+\mathrm{t}_{1}+\mathrm{sp}_{\mathrm{jk}} \\
& +\mathrm{st}_{\mathrm{jl}}+\mathrm{pt}_{\mathrm{kl}}+\mathrm{spt}_{\mathrm{jkl}}+\mathrm{e}_{\mathrm{jklm}}
\end{aligned}
$$

where $y_{j k l m}$ is the fatty acid percentage of individual $\mathrm{m}$ in tissue $\mathrm{l}$ of part $\mathrm{k}$ from sexual group $\mathrm{j} ; \mu, \mathrm{s}_{\mathrm{j}}, \mathrm{p}_{\mathrm{k}}$ are defined as above; $\mathrm{t}_{\mathrm{l}}$ is the tissue effect 1 (1: SK, SB, IM, M); $\mathrm{sp}_{\mathrm{jk}}$, $\mathrm{st}_{\mathrm{jl}}, \mathrm{pt}_{\mathrm{kl}}, \mathrm{spt}_{\mathrm{jkl}}$ are the corresponding second and third order interactions between the effects of the sexual group, the part, and the tissue; $\mathrm{e}_{\mathrm{jklm}}$ is the residual error term. The analyses provided estimates of treatment contrasts and statistical significance of the differences was determined by the t-test.

\section{RESULTS}

\subsection{Age of caponisation}

No differences were found for crude fat content of edible meat (EMF) between CA- 4 and CA- 8 groups; the effects of caponisation age on the fatty acid profiles of abdominal fat and edible meat are given in Table II; at the same time, no effect of caponisation age was found on the fatty acid profile. However, for edible meat, the CA-8 group showed a higher US ratio than the CA-4, mainly as a result of a higher content of C18:2 n-6; as a consequence, PUFA and $n-6$ fatty acids were also higher in CA-8. The increase in C18:2 n-6 was counterbalanced by a decrease in C16:0, thereby explaining the US change. Because of these differences, comparisons between cocks and capons were made only with respect to the CA-8 group, since this is the caponisation age commonly adopted in commercial farms.

\subsection{Fat characteristics of abdominal fat}

The effects of caponisation on total lipid fatty acid profiles of abdominal fat are given in Table III; as we can observe, the US ratio was higher in capons than in cocks 
Table II. Least squares means and residual standard deviation of fatty acid composition (\% total fatty acids) of abdominal fat and edible meat in capons castrated at 4 and 8 weeks $(n=8)$.

\begin{tabular}{|c|c|c|c|c|c|c|}
\hline & \multicolumn{3}{|c|}{ Abdominal fat ${ }^{1}$} & \multicolumn{3}{|c|}{ Edible meat $^{2}$} \\
\hline & \multicolumn{3}{|c|}{ Caponisation age } & \multicolumn{3}{|c|}{ Caponisation age } \\
\hline & Early & Late & RSD & Early & Late & RSD \\
\hline$\overline{\mathrm{C} 14: 0}$ & 0.73 & 0.88 & 0.16 & 0.81 & 0.71 & 0.27 \\
\hline C16:0 & 25.84 & 26.43 & 3.72 & $27.36^{\mathrm{a}}$ & $24.50^{\mathrm{b}}$ & 5.42 \\
\hline C16:1 n-7 & 6.39 & 7.17 & 1.24 & 7.00 & 6.59 & 1.39 \\
\hline C18:0 & 6.15 & 5.17 & 1.00 & 7.21 & 6.52 & 2.19 \\
\hline C18:1 n-9 & 38.62 & 37.61 & 1.90 & 37.85 & 37.72 & 3.99 \\
\hline $\mathrm{C} 18: 2 \mathrm{n}-6$ & 20.54 & 20.99 & 3.00 & $17.34^{\mathrm{b}}$ & $21.40^{\mathrm{a}}$ & 5.82 \\
\hline $\mathrm{C} 18: 3 \mathrm{n}-3$ & 0.77 & 0.88 & 0.13 & 0.79 & 0.89 & 0.26 \\
\hline C20:0 & 0.21 & 0.18 & 0.11 & 0.17 & 0.26 & 0.23 \\
\hline C20:1 n-9 & 0.42 & 0.40 & 0.13 & 0.54 & 0.43 & 0.31 \\
\hline$C 20: 2 n-6$ & 0.16 & 0.13 & 0.10 & 0.35 & 0.25 & 0.35 \\
\hline $\mathrm{C} 22: 0$ & 0.11 & 0.10 & 0.08 & $0.52^{\mathrm{b}}$ & $0.68^{\mathrm{a}}$ & 0.31 \\
\hline SFA & 33.06 & 32.78 & 4.08 & 36.09 & 32.69 & 7.21 \\
\hline MUFA & 45.44 & 45.19 & 2.39 & 45.40 & 44.75 & 4.61 \\
\hline PUFA & 21.48 & 22.01 & 3.08 & $18.49^{b}$ & $22.54^{\mathrm{a}}$ & 5.81 \\
\hline PUFA+MUFA/SFA & 2.07 & 2.07 & 0.33 & $1.87^{\mathrm{b}}$ & $2.12^{\mathrm{a}}$ & 0.48 \\
\hline$\Sigma \mathrm{n}-3$ & 0.77 & 0.88 & 0.13 & 0.79 & 0.89 & 0.26 \\
\hline$\Sigma \mathrm{n}-6$ & 20.70 & 21.13 & 2.99 & $17.70^{\mathrm{b}}$ & $21.65^{\mathrm{a}}$ & 5.67 \\
\hline
\end{tabular}

a, b Different superscripts within rows indicate means which are significantly different $(P<0.05)$.

${ }^{1}$ Adjusted at $280 \mathrm{~g}$ of abdominal fat weight as a covariate.

2 Adjusted at $43.4 \%$ of edible meat fat content as a covariate

SFA, MUFA, PUFA: Saturated, Mono-Unsaturated and Poly-Unsaturated Fatty Acids, respectively.

$\Sigma$-3: sum of n-3 fatty acids; $\Sigma$ n-6: sum of n-6 fatty acids.

at an equal age of slaughter. This difference was due to C18:0 and C16:1 n-7 fatty acids, which led to an increase in the MUFA and to a decrease in the SFA content in capons. However, if adjusted by the abdominal fat weight, the US index did not differ between cocks and capons, nevertheless, the observed differences in C16:1 n-6 and C18:0 still remained, and no difference was observed between capons and cocks in PUFA for abdominal fat.

\subsection{Fat characteristics of edible meat}

Significances for caponisation, part, caponisation with part interaction, and EMF on the fatty acid profile of edible meat are given in Table IV, where it can be observed that the part effect was significant in all fatty acids except C20:1 n-9. Caponisation with part interaction was also significant for several fatty acids, and the effect of caponisation on fat composition of edible meat was part dependent. Besides, a significant interaction between caponisation and part was found for EMF, SFA, PUFA and US; for this reason the effect of caponisation on fat composition of edible meat is given part by part. The EMF percentage was always higher in capons for all parts (Fig. 1) but especially in the thigh and breast.

The fatty acid profiles of the thigh and drumstick are the most sensitive to caponisation (Fig. 2). In both parts, the US ratio was higher in capons than in cocks, as a 
Table III. Least squares means and residual standard deviation of fatty acid composition (\% total fatty acids) of abdominal fat from cocks and capons $(n=20)$.

\begin{tabular}{|c|c|c|c|c|c|c|}
\hline & & & & At 1 & abdomir & \\
\hline & $\mathrm{CK}$ & CA-8 & RSD & CK & CA-8 & RSD \\
\hline C14:0 & 2.05 & 1.78 & 0.88 & 2.06 & 1.76 & 0.89 \\
\hline C14:1 n-9 & 0.57 & 0.53 & 0.27 & 0.46 & 0.60 & 0.26 \\
\hline C16:0 & 28.58 & 29.49 & 3.42 & 28.45 & 29.58 & 3.46 \\
\hline C16:1 n-7 & $4.18^{\mathrm{b}}$ & $6.42^{\mathrm{a}}$ & 1.19 & $4.52^{\mathrm{b}}$ & $6.19^{\mathrm{a}}$ & 1.19 \\
\hline C18:0 & $9.73^{\mathrm{a}}$ & $6.26^{\mathrm{b}}$ & 1.67 & $9.00^{\mathrm{a}}$ & $6.72^{\mathrm{b}}$ & 1.63 \\
\hline C18:1 n-9 & 35.34 & 36.79 & 2.47 & 36.42 & 36.10 & 2.42 \\
\hline C18:2 n-6 & 18.38 & 17.65 & 3.18 & 17.87 & 17.97 & 3.21 \\
\hline $\mathrm{C} 18: 3 \mathrm{n}-3$ & 0.44 & 0.58 & 0.25 & 0.46 & 0.57 & 0.25 \\
\hline C20:0 & 0.12 & 0.09 & 0.08 & 0.13 & 0.09 & 0.08 \\
\hline C20:1 n-9 & $0.29^{\mathrm{a}}$ & $0.20^{\mathrm{b}}$ & 0.12 & 0.30 & 0.19 & 0.12 \\
\hline$C 20: 2$ n-6 & $0.13^{\mathrm{a}}$ & $0.07^{\mathrm{b}}$ & 0.08 & 0.13 & 0.07 & 0.08 \\
\hline $\mathrm{C} 22: 0$ & 0.07 & 0.05 & 0.05 & 0.08 & 0.04 & 0.05 \\
\hline SFA & $40.58^{a}$ & $37.68^{b}$ & 3.90 & 39.74 & 38.22 & 3.92 \\
\hline MUFA & $40.44^{b}$ & $44.00^{\mathrm{a}}$ & 2.93 & 41.77 & 43.14 & 2.87 \\
\hline PUFA & 18.96 & 18.31 & 3.31 & 18.46 & 18.63 & 3.34 \\
\hline PUFA+MUFA/SFA & $1.55^{\mathrm{b}}$ & $1.72^{\mathrm{a}}$ & 0.25 & 1.62 & 1.67 & 0.25 \\
\hline$\Sigma \mathrm{n}-3$ & 0.44 & 0.58 & 0.25 & 0.46 & 0.57 & 0.25 \\
\hline$\Sigma \mathrm{n}-6$ & 18.52 & 17.72 & 3.20 & 18.00 & 18.05 & 3.22 \\
\hline
\end{tabular}

a, b Different superscripts within rows indicate means which are significantly different $(P<0.05)$.

${ }^{1}$ Adjusted as a covariate.

CK: Cocks; CA-8: Capons castrated at 8 weeks of age.

SFA, MUFA, PUFA: Saturated, Mono-Unsaturated and Poly-Unsaturated Fatty Acids, respectively.

$\Sigma$-3: sum of n-3 fatty acids; $\Sigma$ n-6: sum of n-6 fatty acids.

result of higher contents in PUFA and MUFA and lower contents in SFA. For the thigh, the differences between capons and cocks were primarily due to $\mathrm{C} 14: 0(2.11 \pm$ 0.27 vs. $4.22 \pm 0.28 ; P<0.01) ; \mathrm{C} 16: 1 \mathrm{n}-7$ $(6.09 \pm 0.34$ vs. $4.30 \pm 0.35 ; P<0.01)$ C18:0(7.04 \pm 0.38 vs. $11.87 \pm 0.39 ; P<0.01)$ and $\mathrm{C} 18: 2 \mathrm{n}-6(18.08 \pm 0.93$ vs. $13.99 \pm$ $0.96 ; P<0.05)$ fatty acids, respectively. In line with these results, for the drumstick, the differences between capons and cocks were due to $\mathrm{C} 16: 1 \mathrm{n}-7$ (7.79 \pm 0.39 vs. $5.99 \pm$ 0.39; $P<0.01)$; C18:0 (6.98 \pm 0.44 vs. $12.56 \pm 0.44 ; P<0.01) ; \mathrm{C} 18: 2 \mathrm{n}-6(19.49 \pm$ 1.07 vs. $14.64 \pm 1.07 ; P<0.01)$; and $\mathrm{C} 18: 3$ n-3 (0.74 \pm 0.05 vs. $0.40 \pm 0.05 ; P<0.01)$ fatty acids, respectively. Fat changes occur- ring after caponisation led to modifications of fat nutritional characteristics. Therefore, capons showed a higher percentage of omega 3 fatty acids in edible meat from both the drumstick and thigh and a higher percentage of omega 6 fatty acids in the thigh. However, once adjusted by EMF, caponisation only affected the thigh fatty acid composition, where differences, as above, are mainly due to a higher concentration of C16:1 n-7 (7.87 \pm 0.39 vs. $6.36 \pm$ $0.44 ; P<0.05), \mathrm{C} 18: 2 \mathrm{n}-6(19.59 \pm 1.07$ vs. $15.16 \pm 1.22 ; P<0.01)$ and $C 18: 3 \mathrm{n}-3$ $(0.75 \pm 0.05$ vs. $0.43 \pm 0.06 ; P<0.01)$ and lower concentrations of C18:0 (6.79 \pm 0.42 vs. $11.60 \pm 0.48 ; P<0.01)$ in capons; the $n-6 / n-3$ ratio of edible meat was not affected 
Table IV. Statistical significance of the effects of caponisation, part, interaction between caponisation and part, and edible meat fat content (EMF) on fatty acid composition of edible meat.

\begin{tabular}{lccccc}
\hline$\%$ & Overall mean & Caponisation & Part & Caponisation $\times$ part $\%$ EMF (covariate) \\
\hline EMF & 26.11 & $* *$ & $* *$ & $* *$ &.$\cdot$ \\
C14:0 & 1.67 & NS & $* *$ & $* *$ & $* *$ \\
C14:1 n-9 & 0.43 & NS & $* *$ & $*$ & $* *$ \\
C16:0 & 24.93 & NS & $* *$ & NS & NS \\
C16:1 n-7 & 5.88 & $*$ & $* *$ & NS & NS \\
C18:0 & 8.64 & $* *$ & $* *$ & $* *$ & $* *$ \\
C18:1 n-9 & 38.02 & NS & $* *$ & NS & $* *$ \\
C18:2 n-6 & 18.38 & NS & $* *$ & $* *$ & NS \\
C18:3 n-3 & 0.68 & $*$ & $* *$ & NS & NS \\
C20:0 & 0.13 & NS & $*$ & NS & NS \\
C20:1 n-9 & 0.42 & $*$ & NS & NS & NS \\
C20:2 n-6 & 0.36 & NS & $* *$ & $* *$ & $* *$ \\
C22:0 & 0.42 & NS & $* *$ & NS & $*$ \\
SFA & 35.81 & NS & $* *$ & $* *$ & $* *$ \\
MUFA & 44.75 & NS & $* *$ & NS & $* *$ \\
PUFA & 19.43 & NS & $* *$ & $* *$ & NS \\
MUFA+PUFA/SFA & 1.87 & NS & $* *$ & $* *$ & $* *$ \\
$\Sigma \mathrm{n}-3$ & 0.68 & $*$ & $* *$ & NS & $* *$ \\
$\Sigma \mathrm{n}-6$ & 18.74 & NS & $* *$ & NS \\
\hline
\end{tabular}

*, ** Significant at $P<0.05$ and $P<0.01$, respectively.

SFA, MUFA, PUFA: Saturated, Mono-Unsaturated and Poly-Unsaturated Fatty Acids, respectively.

$\Sigma$-3: sum of n-3 fatty acids; $\Sigma$ n-6: sum of n-6 fatty acids.

by caponisation but was part dependent $(P<0.01)$. Both in cocks and capons, the highest $n-6 / n-3$ ratio $(53.7 \pm 5.4)$ took place in the thigh, reaching twice as much as the other three parts.

\subsection{Fat characteristics of edible meat constituent tissues}

Fatty acid profiles of edible meat constituents were studied separately. For intramuscular fat content, SFA, PUFA and US, the interaction effect between caponisation, part and tissue was statistically significant. Hence, the effect of caponisation on the aforementioned indexes on each tissue is given within part (Tab. V), where the tissue effect is statistically significant for fat con- tent and all fatty acids. Additionally, the r-square outstandingly improved for fat contents (from 0.67 to. 0.96) and for the majority of fatty acids (in short, 0.49 vs. $0.77 ; 0.36$ vs. 0.80 and 0.29 vs. 0.37 for SFA, MUFA and PUFA, respectively). With regards to fat content, the caponisation effect was focused on skin and subcutaneous fat, and skin fat content in capons was about twice than in cocks in all studied parts. The subcutaneous breast, thigh and drumstick fat content also showed to be higher in capons than in cocks. Surprisingly, in the drumstick, cocks had an extremely lower value, and differences with respect to capons in this tissue reached $37 \%$. Capons showed higher intramuscular fat than cocks after pooling of all parts $(8.32 \% \pm 0.48$ vs. $5.81 \% \pm 0.51 ; P<0.001)$, 


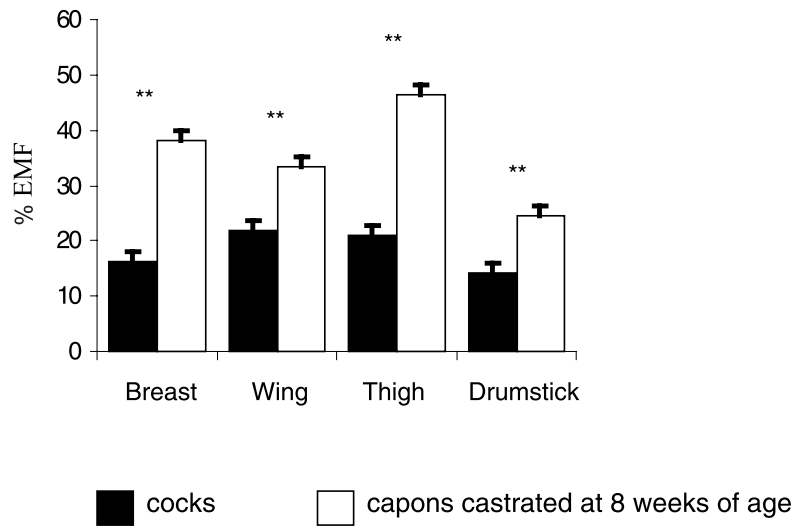

Figure 1. Least squares means and S.E. (T) of edible meat fat (EMF) content by part at slaughter age of 28 weeks. (** significant at $P<0.01$ ).

although the differences were not significant when comparisons were done part by part (Tab. V). Fatty acid profiles for meat constituent tissues by part can be seen in Table V; in several cases, muscle gives rise to lower saturation in capons. Thus, intramuscular fat in the drumstick presents a higher content of PUFA and a lower content of SFA in capons than in cocks, whereas thigh intramuscular fat presents a higher content of MUFA and lower SFA rates in capons. Breast intramuscular fat presents higher content of MUFA; however, the breast and wing present a higher intramuscular PUFA content in cocks than in capons. In line with these results, thigh skin follows a similar model since thigh muscle also presents a higher content of MUFA and lower rate of SFA in capons. Intermuscular fat in the breast and wing presents a higher SFA content in cocks than in capons.

\section{DISCUSSION}

\subsection{Growth and tissue composition}

Despite the fact that fat growth is the last step in tissue development sequence, early caponisation has an effect on meat characteristics. The most important changes, raised by advancing caponisation age in 4 weeks, are a lower US ratio and PUFA percentage in EMF (Tab. II), together with a small incre- ment in carcass skin percentage reported in a previous work [23]. These results were in accordance with the bibliography [19], showing that the effects of gonadal development on fat deposition may start very early in time. Moreover, differences in growth curves between cocks and capons started at caponisation time [5] and should explain several carcass differences found in meat. In this sense, changes by caponisation in the US ratio of abdominal fat could be most likely explained by a higher growth of this tissue in capons, because at constant abdominal path weight whole differences disappear. However, EMF composition has a more complex behaviour. Despite the fact that EMF as a covariate is significant, caponisation and part interaction effect still remains significant in SFA, MUFA and US indexes and in several fatty acids (Tab. IV). Therefore, reasons other than faster growth in capons are needed to explain differences in EMF composition. In this sense, including the tissue effect in the statistical model is a useful means of explaining fat and fatty acid variances in edible meat. An overall view on tissue composition by parts (Tab. V) looks anarchical and there seems to be no underlying pattern between parts. Although detected changes in tissues agree with whole EMF part differences previously described, a direct relationship between tissue and meat composition is not always evident. Two reasons could explain this fact. Firstly, 

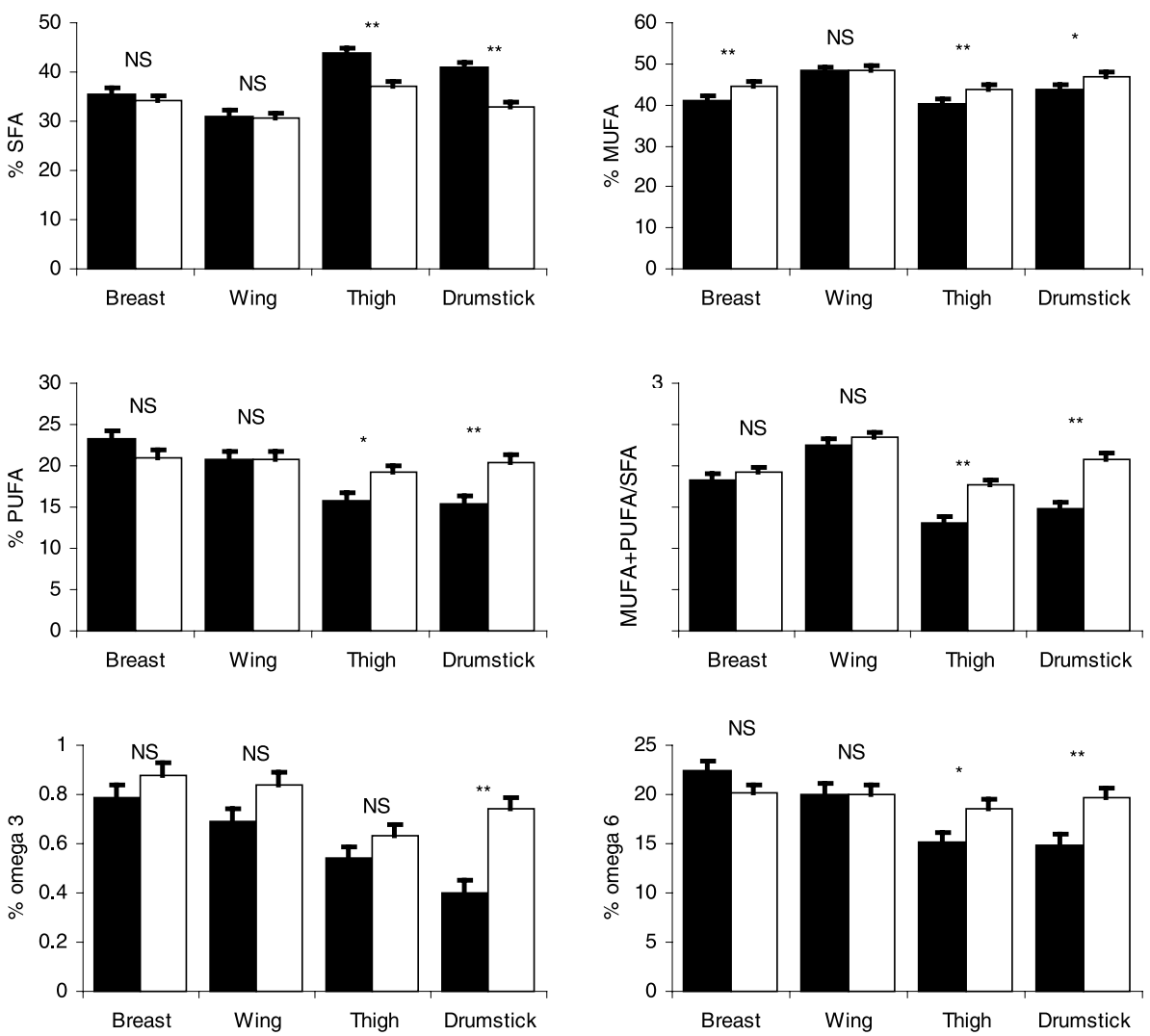

cocks

capons castrated at 8 weeks of age

Figure 2. Least squares means of summarised fatty acid profiles of edible meat by part at slaughter age of 28 weeks. (*, ** significant at $P<0.05$ and $P<0.01$, respectively). SFA, MUFA, PUFA $=$ Saturated, Mono-Unsaturated and Poly-Unsaturated Fatty Acids, respectively.

tissue composition must be counterbalanced by tissue weight; in some cases a quantitatively unimportant tissue (for example: intermuscular adipose tissue in the breast) does not extend its influence to EMF. Secondly, opposing differences by tissues compensates in meat as a whole (for example: SFA content of intermuscular and muscle in the wing). Nonetheless, detailed fatty acid composition analysis by parts and tissues has been a useful method to clarify meat differences between cocks and capons. Thus, higher EMF contents in capons is caused by skin and subcutaneous tissues, while a higher US ratio in EMF of capon thigh and drumstick is caused to a large extent by intramuscular fat.

\subsection{Physiological basis}

In a previous paper [23], concerning the carcass quality of the same experiment, we 
Table V. Least squares means and residual standard deviation of summarised fatty acid profiles (\% total fatty acids) of meat tissues by parts $(n=12)$.

\begin{tabular}{|c|c|c|c|c|c|c|c|c|c|}
\hline \multirow[b]{2}{*}{$\%$} & \multicolumn{2}{|c|}{ Breast } & \multicolumn{2}{|c|}{ Wing } & \multicolumn{2}{|c|}{ Thigh } & \multicolumn{2}{|c|}{ Drumstick } & \multirow[t]{2}{*}{ RSD } \\
\hline & CK & CA-8 & $\mathrm{CK}$ & CA-8 & CK & CA-8 & $\mathrm{CK}$ & CA-8 & \\
\hline \multicolumn{10}{|l|}{$\overline{F A T}$} \\
\hline Skin & $24.6^{\mathrm{b}}$ & $53.5^{\mathrm{a}}$ & $26.4^{\mathrm{b}}$ & $48.6^{\mathrm{a}}$ & $30.9^{\mathrm{b}}$ & $70.8^{\mathrm{a}}$ & $12.2^{\mathrm{b}}$ & $34.7^{\mathrm{a}}$ & । \\
\hline Subcutaneous & $81.7^{\mathrm{b}}$ & $91.5^{\mathrm{a}}$ & - & - & $81.9^{\mathrm{b}}$ & $94.6^{\mathrm{a}}$ & $46.3^{\mathrm{a}}$ & $83.7^{\mathrm{b}}$ & 6.45 \\
\hline Muscle & 1.9 & 3.3 & 5.6 & 6.8 & 7.59 & 11.6 & 8.2 & 11.3 & I \\
\hline \multicolumn{10}{|l|}{$S F A$} \\
\hline Skin & 35.1 & 33.6 & 29.0 & 28.4 & $31.3^{\mathrm{a}}$ & $26.6^{\mathrm{b}}$ & 33.8 & 32.3 & I \\
\hline Subcutaneous & 35.0 & 34.7 & 30.4 & 30.2 & 41.3 & 39.6 & 32.3 & 31.0 & 4.47 \\
\hline Intermuscular & $22.0^{\mathrm{a}}$ & $18.0^{\mathrm{b}}$ & $17.9^{\mathrm{a}}$ & $13.3^{\mathrm{b}}$ & 31.3 & 30.9 & 22.0 & 23.3 & । \\
\hline Muscle & 38.3 & 36.3 & $33.6^{\mathrm{b}}$ & $37.5^{\mathrm{a}}$ & $51.4^{\mathrm{a}}$ & $45.1^{\mathrm{b}}$ & $40.9^{\mathrm{a}}$ & $36.5^{\mathrm{b}}$ & । \\
\hline \multicolumn{10}{|l|}{$M U F A$} \\
\hline Skin & 44.3 & 47.0 & 51.8 & 52.9 & $50.9^{\mathrm{b}}$ & $56.5^{\mathrm{a}}$ & 46.6 & 49.0 & I \\
\hline Subcutaneous & 43.4 & 45.7 & 49.4 & 49.1 & 40.7 & 44.3 & 47.3 & 50.2 & 4.49 \\
\hline Intermuscular & 61.9 & 65.5 & 70.2 & 73.5 & 49.0 & 50.2 & 57.4 & 57.2 & I \\
\hline Muscle & $41.9^{\mathrm{b}}$ & $46.2^{\mathrm{a}}$ & 45.8 & 45.0 & $31.1^{\mathrm{b}}$ & $36.7^{\mathrm{a}}$ & 42.0 & 44.2 & । \\
\hline \multicolumn{10}{|l|}{ PUFA } \\
\hline Skin & 20.6 & 19.4 & 19.1 & 18.7 & 17.8 & 16.9 & 20.0 & 18.7 & । \\
\hline Subcutaneous & 21.6 & 19.5 & 20.2 & 20.7 & 18.0 & 16.1 & 20.4 & 18.8 & 2.80 \\
\hline Intermuscular & 16.1 & 16.5 & 11.9 & 13.1 & 19.6 & 18.8 & 20.6 & 19.5 & 1 \\
\hline Muscle & $19.8^{\mathrm{a}}$ & $17.5^{\mathrm{b}}$ & $20.6^{\mathrm{a}}$ & $17.5^{\mathrm{b}}$ & 17.5 & 18.2 & $17.1^{\mathrm{a}}$ & $19.3^{b}$ & । \\
\hline
\end{tabular}

a,b Different superscripts within rows indicate means which are significantly different $(P<0.05)$. CK: Cocks, CA-8: Capons castrated at 8 weeks of age.

SFA, MUFA, PUFA: Saturated, Mono-Unsaturated and Poly-Unsaturated Fatty Acids, respectively.

have reported a higher abdominal and subcutaneous adipose tissue in capons. Because fat synthesis in birds is mainly hepatic [1], these changes were explained by an increased rate of hepatic lipogenesis in capons [14] due to a feminisation of the growth hormone secretion pattern by caponisation [18]. In order to explain changes in abdominal fat composition and a higher fat content in subcutaneous adipose tissue of capons, the same physiological background should be argued. In this case, because birds, as well as mammals lack 12-desaturase and 15-desaturase, changes in fatty acid profiles could be expected. Thus, higher endogenous synthesis of saturated and monounsaturated fatty acids should lead to a fall in PUFA levels. Our results in EMF composition disagree with these expectations, since PUFA levels either remain constant (breast and wing) or increase (thigh and drumstick) in capons. Therefore, in opposition to divergent selected lines for fatness [1], higher EMF contents in capons must be explained by a higher deposition of fat from the diet rather than by a de novo synthesis. This necessarily implies a higher ingestion and/or higher digestibility in capons, since 
birds are tributaries of food intake for these fatty acids [16]. In this sense, an improvement in conversion indexes was reported by Francesch [10] in Penedesenca Negra capons; in our experiment, we observed the same trend, and thus, from 7 to 28 weeks of age, the group conversion index was 6.58 and 6.17 for cocks and capons, respectively (data not published). Unfortunately, individual food intake records were not available. Whatever might be the case, further investigations are still necessary to gain insight into the physiological basis of higher fatness in capons.

\subsection{Meat quality}

Changes in meat quality of capons related to fat characteristics present contrasting aspects. Given that all parts from the capon's carcass are fattier than those from cocks, both sensorial and dietetic characteristics in capons would change. According to the literature, higher fat content usually involves a decrease in consumer willingness to purchase and eat the meat. This fact could be counterbalanced by an improvement of texture and taste, especially in this reputed product. With regards to dietetic characteristics, high fat content clashes with general advice of nutritionists. However, the greater US ratio of capon EMF, as a result of lower SFA content in the drumstick and thigh muscle, counterbalances dietetic meat quality in capons, since it is clear that saturated fatty acids are hypercholesterolemic [13]. Moreover a higher n-3 content in the drumstick of capons underlines its EMF quality with regards to cocks; unlike in most cases, [8] a higher fat level in capons does not result in n-6/n-3 changes. Finally, a higher trend in capons to deposit a more polyunsaturated fat could make it necessary to provide an extra antioxidant intake, as advised in omega-3 fatty acid enriched diets [16].

\section{CONCLUSIONS}

Caponisation increases chemical fat content in all parts, mainly as a result of a greater accumulation of fat in the skin and in subcutaneous adipose tissue. Increased fatness leads to some modifications in fat characteristics, particularly in the thigh and in the drumstick, where the fatty acid profile of edible meat shows a less saturated pattern. The fatty acid profile of the breast as a whole is not seriously affected by caponisation but the profile of the dissected muscle is more monounsaturated in capons. The profile of abdominal fat is less saturated in capons, although this effect vanishes after adjusting by means of abdominal pad weight. All changes occurring on fat quality after caponisation indicate that increased fatness in capons does not mean worse fat nutritional properties. The sensorial characteristics will probably be more dependent from the lipid amount in tissues than from the fatty acid profile. Particularly the PUFA, quite implicated in flavour development, does not greatly differ between cocks and capons.

\section{ACKNOWLEDGEMENTS}

Financial support for the experiment was provided by Empresa Sendra-Majorista d'Aus and Universitat de Lleida (grant No. UdL-C0259) and CICYT (grant No. AGF99-1221). The authors would like to thank A. Naco for laboratory analyses. SEDAI d'Anàlisi Cromatogràfic, UdL, offered invaluable help and advice on the determination of the fatty acid profiles.

\section{REFERENCES}

[1] Alleman F., Bordas A., Caffin J.P., Daval S., Diot C., Douaire M., Raslin J.M., Lagarrigue S., Leclercq B., L'engraissement chez le poulet : aspects métaboliques et génétiques, INRA Prod. Anim. 12 (1999) 257-264.

[2] American Hearth Association, Dietary guidelines for healthy American Adults, Circulation 4 (1986) 1465-1468.

[3] AOAC, Official Methods of Analysis, Association of Official Analytical and Chemists, Washington, DC, 1997. 
[4] Cason J.A., Fletcher D.L., Burke W.H., Effects of caponisation on broiler growth, Poult. Sci. 67 (1988) 979-981.

[5] Cubiló M.D., Tor M., La castración precoz en la producción de capones, Nuestra Cabaña 5 (1999) 72-74.

[6] Cubiló M.D., Villalba D., Estany J., Francesch A., Tor M., Efecto de la castración sobre el crecimiento de los gallos de la raza Penedesenca Negra, XXXVII Symposium de Avicultura WPSA, Barcelona, Spain, 2000, p. 167.

[7] D.O.G., Diari Oficial de la Generalitat de Catalunya, Barcelona, Spain, 879, 1987, pp. 3328-3329.

[8] De Smet S., Raes K., Demeyer D., Meat fatty acid composition as affected by fatness and genetic factors: a review, Anim. Res. 53 (2004) 81-89.

[9] Francesch A., Funcionamiento de la conservación de razas de gallinas autoctonas en Catalunya, Arch. Zootec. 47 (1998) 141-148

[10] Francesch A., Fortuny M.R., Farran M., GarciaMartín E., Extensive breeding and castration effects on the productivity and carcass quality of local breeds chickens, Proceedings of the International Symposium on basis of the quality of typical Mediterranean animal products, EAAP Publications, 1998, p. 487.

[11] Hanson S.W.F., Olley J., Application of the method of lipid extraction to tissue homogenate, Biochem. J. 89 (1963) 101-102.

[12] Kris-Etherton P.M., Yu S., Individual fatty acid effects on plasma lipids and lipoproteins: human studies, Am. J. Clin. Nutr. 65 (1997) 1628-1644.

[13] Kris-Etherton P.M., Krummel D., Russell M.E., Dreon D., Mackey S., Borchers J., Wood P.D., The effect of diet on plasma lipids, lipoproteins, and coronary heart disease, J. Am. Diet. Assoc. 88 (1988) 1373-1400.

[14] Kompiang I.P., Gibson W.R., Effect of hypophysectomy and insulin on lipogenesis in cockerels, Horm. Metab. Res. 8 (1976) 340345.

[15] Leenstra F.R., Vries A.D., De Vries A.W., Genetic aspects of meat quality in poultry, Proceedings of the 4th World Congress on
Genetics applied to Livestock Production, sheep and pig genetics and breeding, fibre, fur and meat quality, Edinburgh, Scotland, 1990, p. 531 .

[16] Lessire M., Matières grasses alimentaires et composition lipidique des volailles, INRA Prod. Anim. 14 (2001) 365-370.

[17] Lopez F.S., Baucells M.D., Barroeta A.C., Grashorn M.A., Influence of vegetable oil sources on quality parameters of broiler meat, Arch. Geflugelkd. 63 (1999) 29-35.

[18] Pampori N.A., Shapiro B.H., Testicular regulation of sexual dimorphism in the ultradian profiles of circulating growth hormone in the chicken, Eur. J. Endocrinol. 131 (1994) 313318.

[19] Rahman M.A., Ross S.D., Fanguy R.C., Hyatt D.A., The influence of gonadal development on lipid accretion in commercial broilers, Poult. Sci. 63 (Suppl. 1) (1984) 167.

[20] Rule D.C., Direct transesterification of total fatty acids of adipose tissue, and of freezedried muscle and liver with boron-trifluoride in methanol, Meat Sci. 46 (1997) 23-32.

[21] SAS, SAS/STAT User's Guide: statistics, SAS Inst. Inc., Cary, North Caroline, 1996.

[22] Tor M., Caracterització del teixit adipós en xais amb denominació específica Ternasco de Aragón. Variacions segons la raça i la qualitat de la canal, Ph.D. dissertation, Universitat de Lleida, Spain, 1997, 147 p.

[23] Tor M., Estany J., Villalba D., Molina E., Cubiló M.D., Comparison of carcass composition by parts and tissues between cocks and capons, Anim. Res. 51 (2002) 421-431.

[24] Winter A.R., Funk E.M., Poultry Science and practice, J.B. Lippincott Co., New York, 1960, $739 \mathrm{p}$.

[25] W.P.S.A., Working Group No. 5, Method of dissection of broiler carcasses and description of parts, Frish Jensen, 1984, 33 p.

[26] York L.R., Mitchell J.D., The effect of estradiol-17-monopalmitate and surgical caponisation on production efficiencies, yields and organic characteristics of chicken broilers, Poult. Sci. 48 (1969) 1532-1536. 